\title{
Gestão do Marketing Esportivo no futebol: proposta de modelo teórico/prático para clubes profissionais brasileiros
}

\author{
Sport Marketing management in football: proposal for a \\ theoretical/practical model for Brazilian professional clubs
}

MORAES, Ivan Furegato. Gestão do Marketing Esportivo no futebol: proposta de modelo teórico/prático para clubes profissionais brasileiros. 2020. 405 f. Tese (Doutorado em Ciências) - Escola de Educação Física e Esporte, Universidade de São Paulo, São Paulo. 2020.

Resumo: A partir da década de 1990 a expansão global e o desenvolvimento econômico do futebol se aceleraram, transformando-o em um rentável negócio inserido na Indústria do Entretenimento. Nesse contexto, o Marketing Esportivo (ME), até então pouco utilizado pelos clubes, ganhou relevância ao atender às necessidades e desejos dos torcedores e gerar elevadas receitas. Apesar do desenvolvimento e da relevância para os clubes - principalmente os europeus -, no Brasil, até os dias atuais, o ME é utilizado parcialmente pelos clubes, os quais não se beneficiam de todas as suas potencialidades. Em paralelo, a temática se tornou alvo de estudos acadêmicos que buscaram defini-la e desenvolver ferramentas e modelos para a sua gestão nas organizações esportivas, especialmente processos de planejamento, estruturação, execução e avaliação/controle. Contudo, no Brasil o tema ainda é pouco explorado, não havendo um modelo de gestão que considere aspectos teóricos e as peculiaridades dos clubes locais. A partir desse contexto a pesquisa objetivou propor um modelo teórico/prático para a gestão do ME nos clubes de futebol profissionais brasileiros adequado à sua realidade a partir de elementos oriundos dos modelos teóricos de gestão do Marketing e do Marketing Esportivo e da prática realizada pelos clubes. A pesquisa se caracteriza como aplicada, exploratória e qualitativa, sendo realizada em quatro etapas: (i) revisão bibliográfica sobre modelos organizacionais e de gestão do Marketing e do ME; (ii) pesquisa de campo realizada por meio de entrevistas em profundidade semiestruturadas com os responsáveis pela área de marketing dos clubes participantes da Série A1 do Campeonato Paulista de 2018, com os dados analisados por meio do processo de codificação e categorização; (iii) análise comparativa entre os resultados das etapas anteriores para evidenciar pontos convergentes e divergentes; e (iv) identificação dos principais elementos para a gestão do ME nos clubes brasileiros e proposta do modelo. Na Etapa I foram identificados modelos organizacionais e de gestão do Marketing e do ME para organizações esportivas e clubes de futebol, com destaque para seis: os baseados na Administração de Marketing, na parte comercial, na marca, no Marketing de Serviços, no Marketing de Relacionamento e no Marketing de Experiência. Na Etapa II foram identificadas 40 categorias que apresentaram detalhadamente como os clubes gerem o marketing. Por fim, foram identificados 38 elementos fundamentais para a gestão do ME, sendo propostos dois modelos 
para a estruturação dos departamentos de marketing e um modelo para o planejamento, execução, avaliação e controle, formado por 18 fases. Os modelos apresentados, bem como seus elementos, podem ser aplicados à clubes brasileiros ou estrangeiros, de diferentes portes e realidades, já que podem ser facilmente adaptados. Espera-se que o estudo sirva de guia para os profissionais da área e como base e incentivo para novas pesquisas sobre a temática.

Palavras-chave: Marketing Esportivo; clubes de futebol; modelo de gestão de Marketing Esportivo.

MORAES, Ivan Furegato. Sport Marketing management in football: proposal for a theoretical/practical model for Brazilian professional clubs. 2020. $405 \mathrm{f}$. Thesis (Doctorate in Science) - Escola de Educação Física e Esporte, Universidade de São Paulo, São Paulo. 2020.

Abstract: Since the 1990s the global expansion and economic development of football have accelerated, turning football into a rentable business inserted into the Entertainment Industry. In this context, Sport Marketing (SM), until then almost not applied by clubs, has gained relevance by fulfilling the needs and desires of fans and by generating high revenues. Despite its development and relevance to clubs - mainly the European ones - in Brazil, until recently, SM is only partially applied by clubs, which do not benefit from all its potentialities. In parallel, the thematic has become a target for academical studies that aimed to define it and to develop tools and models for its management on sports organizations, specially planning processes, structuring, execution and evaluation/control. However, in Brazil such theme is little explored since there isn't a management model that considers theoretical aspects and the peculiarities of local clubs. From this context the research aimed to propose a theoretical/practical model of SM management to Brazilian professional football clubs that relates to their reality starting from elements that are originated on theoretical models of Marketing and Sport Marketing management and on the practices of such clubs. This research is characterized as applied, exploratory, and qualitative and was carried out on in four stages: (i) bibliographic review of organizational and management models of Marketing and SM; (ii) field research by the means of in-depth and semi-structured interviews with the ones responsible for the marketing area on participant clubs of A1 Series of the Campeonato Paulista de 2018, being the data analyzed by the process of codification and categorization; (iii) comparative analysis of the previous stages results in order to evidentiate converging and diverging points; and (iv) identification of the main elements for SM management on Brazilian clubs along with model proposal. On Stage I were identified organizational and management models for Marketing and SM to sports organizations and football clubs, with emphasis on six: the ones based on Marketing Administration, on the commercial area, on brand, on Service Marketing, on Relationship Marketing, and on Experience Marketing. On Stage II were identified 40 categories that presented in details how clubs manage marketing. At last, 38 fundamentals elements were identified for SM management leading to the proposal of two models for the structure of marketing departments and one model for the planning, execution, 
evaluation, and control, constituted of 18 levels. Presented models, as their elements, can be applied to Brazilian or foreigner clubs, of different sizes and realities, since they can be easily adapted. It is expected that such study can serve as a guide to professionals of the area and as a starting point and incentive to new researches on this thematic.

Keywords: Sport Marketing; football clubs; Sport Marketing management model 